\title{
Growth performance and nutrient digestibility of broilers fed different type of diets and feed additives
}

\author{
C. L. Nalle ${ }^{\mathrm{a} *}$, Helda ${ }^{\mathrm{a}}$, N. Toelle ${ }^{\mathrm{b}}$ and U. Mawadah ${ }^{\mathrm{a}}$ \\ ${ }^{a}$ Feed Technology Study Program, Department of Animal Husbandry, \\ State Polytechnic of Agricuture Kupang \\ ${ }^{b}$ Animal Health Study Program, Department of Animal Husbandry, \\ State Polytechnic of Agricuture Kupang \\ Jl. Prof. Herman Yohanes, Kupang, Nusa Tenggara Timur, Indonesia \\ Corresponding E-mail : nallecatootjie@gmail.com
}

Received April 12, 2021; Accepted July 31, 2021

\begin{abstract}
ABSTRAK
Penelitian ini bertujuan untuk mengevaluasi kecernaan nutrien dan performans pertumbuhan ayam broiler yang diberi jenis ransum (JR) dan imbuhan pakan (IP) yang berbeda. Sejumlah 264 anak ayam broiler umur sehari (jantan, Lohmann) didistribusikan secara acak ke dalam 24 petak (11ekor/ petak). Penelitian dirancang menggunakan rancangan acak lengkap pola faktorial $2 \times 4$ dengan faktor utama JR dan IP. Hasil analisis statistik menunjukkan bahwa interaksi JR x IP berpengaruh ( $\mathrm{p}<0,05$ $0,001)$ terhadap konsumsi ransum (KR) dan pertambahan bobot badan (PBB), tetapi tidak memengaruhi $(\mathrm{p}>0,05)$ FCR ayam broiler fase starter. JR dan JR x IP mempengaruhi $(\mathrm{p}<0,05)$ bobot hati dan panjang proventriculus dan gizzard $(\mathrm{p}<0,05-0,001)$. Kecuali pati, JR tidak memengaruhi $(\mathrm{p}>0,05)$ kecernaan nutrien $(\mathrm{KN})$ dan nilai energy $(\mathrm{NE})$. Kecuali protein kasar, IP tidak memengaruhi $(\mathrm{p}>0,05)$ $\mathrm{KN}$ dan NE. Interaksi JR x IP tidak memengaruhi ( $>00.05) \mathrm{KN}$ dan NE. Jenis ransum (JR) berpengaruh $(p<0,05-0,001)$ terhadap KR dan PBB ayam broiler fase starter. Kecuali hari ke-7, IP memengaruhi $(\mathrm{p}<0,01-0,001) \mathrm{KR}$ dan PBB ayam broiler fase starter. Sebagai simpulan, 1) penambahan sinbiotik and enzim komplek (EK) pada ransum dedak padi-putak (RDP) meningkatkan PP ayam broiler dan 2) multi enzim dan EK bekerja dengan baik pada RDP; 3) RDP menghasilkan performans pertumbuhan ayam broiler starter yang lebih baik.
\end{abstract}

Kata Kunci : Broiler, Enzim, Imbuhan Pakan, Kecernaan Nutrien, Performans.

\begin{abstract}
This research aimed to evaluate the nutrient digestibility and the growth performance of broilers fed a different type of diet (TD) and feed additives (FA). A total of 264 day-old chicks (male, Lohmann) were randomly distributed into 24 pens ( 11 birds/pen). The experiment was designed by using a $2 \times 4$ factorial completely randomized design with the main factors TD and FA. The result shows that TD x FA interaction was significant $(\mathrm{p}<0.05-0.001)$ for feed intake (FI) and body weigt
\end{abstract}


gain (BWG) of starter broilers. The TD, FA, and TD x FA affected $(\mathrm{p}<0.01-0.001)$ growth performance (GP) of growing broilers. TD and TD x FA interaction affected liver weight and the length of proventriculus and gizzard ( $p<0.05$ to 0.001$)$. Except for starch, the TD did not affect ( $p>0.05)$ nutrient digestibility (ND) and energy values (EV). Except for crude protein, FA did not affect ( $p>0.05)$ on ND and EV. The TD $x$ FA interaction did not affect ND and EV. TD affected $(p<0.05-0.001)$ on FI and BWG)of starter broilers. Except for day 7, FA influenced $(\mathrm{p}<0.01-0.001)$ FI and BWG of starter broilers. In conclusion, 1) The addition of Synbiotics and Allzyme SSF-E on Rice bran-sago diet (RSD) improved the GP of birds; and 2) The complex and multi enzymes work well in the rice bran-sago diet 3) RSD produced better growth performance of broiler starter.

Keywords: Broiler, Enzyme, Feed Additive, Nutrient Digestibility, Performance

\section{INTRODUCTION}

Corn and soybean meal are the most common feed ingredients used in the poultry feed industry in Asian Countries and other parts of the world. However, the high price, the availability, and anti-nutritional factors (ANFs) are the fundamental problems related to the utilization of these materials in the diets. Both corn and soybean meal contains non-starch polysaccharides (NSP) that can interfere in nutrient digestibility. Ward (2014) reported that the total NSP content of corn was $8.3 \%$ which comprised of arabynoxylan $(4.3 \%)$, cellulose $(2 \%)$, pectins $(0.9 \%)$, bglucans $(0.3 \%)$, oligosacchararides $(0.3 \%)$. While, the total NSP content of soybean meal (SBM) was reported to be $28.7 \%$, comprising of arabynoxylan $(0.4 \%)$, cellulose $(5.9 \%)$, pectins $(9.1 \%)$, b-glucans $(0.7 \%)$, oligosacchararides $(9.6 \%)$. Soybean meal also contains protease inhibitor, lectins, glycinin, $\beta$-conglycin, oligosaccharides, phytic acid (Yasothai, 2016; Mukherjee et al., 2018). The negative effects of these antinutritional factors reduces nutrient density and reduces the amount of energy metabolized by broilers. Stefanello et al. (2016) reported that the crude protein (CP) and crude fat (CF) digestibility of maize-soy diet were $69.3 \%$ and $86.7 \%$, respectively. This indicated that $21.7 \% \mathrm{CP}$ and $14.3 \%$ CF were not digested.

The alternative feed ingredients which are potential to be used to solve the scarcity and the high price problems of corn are sago (putak meal) and rice bran. Nalle et al. (2017) reported that sago could be included in broiler diets up to $200 \mathrm{~g} / \mathrm{kg}$ with no detrimental effects. However, sago also contains fiber and several antinutritional factors such as tannin, phytic acid, and flavonoids which could impair growth rate, digestive tract development, and nutrient digestibility (Nalle et al. 2021; Nalle et al., 2019). The neutral detergent fiber (NDF) content of sago was 18.9-26.7\% (Nalle et al., 2017, 2019); while, the NDF content of rice bran was $61.7 \%$. The phytic acid content of rice bran was 50.5$84.8 \mathrm{~g} / \mathrm{kg}$ DM (Garcia et al., 2012; Kaur et al., 2011); while in sago was reported $30,61 \mathrm{~g} / \mathrm{kg}$ (Nalle et al., 2019, 2021).

The nutritional improvement of diets containing sago and rice bran through the fermentation process and different feed additives are limited (Nalle et al., 2019, 2020, 2021). Based on the above explanation, corn, soybean meal, sago, and rice bran contain fiber and anti-nutritional factors which may reduce nutrient digestibility, feed efficiency, and production performance of broilers (Selle et al., 2000; Bao et al., 2013).

Many research has been conducted to improve the nutritional value of maize-soybean meal diets through enzyme supplementation (Stefanello et al., 2016; Zhu et al., 2014; Coppedge et al., 2012; Yegani and Korver, 2013; Gehring et al., 2013). However, the efficacy of each type of enzyme is different based on the dose of enzyme and the level of anti-nutritional factors present in the diet. Xylanase, $\beta$ glucanase, pectinase, phytase are exogenous enzymes that are added to the diet to hydrolyze 
xylan, $\beta$-glucan, pectin, and phytic acid in the chicken gut. While, the addition of exogenous enzymes (single or complex) and or other feed additives such as Synbiotics in sago diets is very -very limited (Nalle et al., 2020).

Up to the present time, different feed additives have been produced and sold with different prices, compositions, and efficacy. For example, Allzyme-SSF is a complex enzyme that contains seven active enzymes (amylase, protease, bglucanase, cellulase, xylanase, pectinase, and phytase) that work simultaneously. Avizyme is also a complex enzyme that contains amylase, protease, and xylanase; while Phyzyme is a single enzyme product that contains the only phytase. Probio FMplus is a synbiotics product that contains Lactobacillus spp. as the main microbes. The evaluation of the efficacy of those feed additives in corn-soy and corn-sago-rice bran-soy diets is still limited.

The improvement of the nutritional value of poultry diets with the correct type and dosage of feed additives would help the feed industry and farmers to gain more benefits. The present study was conducted to evaluate the efficacy of different feed additives used in a different types of broiler diets.

\section{MATERIALS AND METHODS}

\section{Animal Ethics}

The handling procedures of animals in the present study were reviewed and approved by the Animal Ethics Committee of the Faculty of Veterinary Medicine, University of Nusa Cendana Kupang-Indonesia, with Ethical Clearance Number $002 / \mathrm{KEH} / \mathrm{SK} / 08 / 2020$ on August $18^{\text {th }}, 2020$.

\section{Birds and Housing}

The present study was conducted in the State Polytechnic of Agriculture Kupang, East Nusa Tenggara Province, Indonesia. A total of 264 one-day-old male broiler chicks (Lohmann strain), provided by PT Japfa Comfeed Tbk Indonesia (as in-kind contribution), were weighed individually using a digital balance (maximum 2 $\mathrm{kg}$, readability $0.01 \mathrm{~g}$ ) to get the initial body weight. Then, every eleven birds were randomly taken, weighed, and distributed to 24 pens from day 1 to day 21 . The average initial body weight was $43.60 \pm 0.34 \mathrm{~g} / \mathrm{bird}$. During the starter period, the birds were kept on the floor pen which was covered with the husk paddy litter. One gasolec unit was used as a heater for chicks and a light bulb (75 watts) was placed in each pen for additional heating. A thermo-hygrometer was placed on each side of the wall to monitor the room temperature and relative humidity. The birds were fed starter diets in crumble form (Table 1).

From day 22 to day 35, the birds were transferred to the metabolic cages for apparent metabolizable energy and digestibility assay. The birds were fed a grower diet in pellet form (Table 2) and given fresh drinking water (ad libitum basis). Synbiotics were added through drinking water for a group of birds that received Synbiotics.

\section{Feed Ingredients}

Maize, sago (Putak meal), and rice bran were purchased from the local distributors in the Kupang area. Synbiotics Probio FM ${ }^{\text {plus }}$ was provided by Feed Technology Laboratory, State Polytechnic of Agriculture Kupang, Indonesia. This synbiotics product contains lactic acid bacteria such as Lactobacillus brevis, Lactobacillus fermentum, Lactobacillus plantarum, and Pediacoccus pentosaceus in an amount ranging from $36.1 \times 10^{11}$ to $210 \times 10^{11} \mathrm{CFU} / \mathrm{mL}$, with the $\mathrm{pH}$ between 3.00 and 3.40. The recommended dosage of synbiotics Probio FMplus used was $20 \mathrm{~mL} /$ $\mathrm{L}$ drinking water. In this experiment, however, the level of synbiotics Probio FMplus used was $40 \mathrm{~mL} / \mathrm{L}$ drinking water. Avizyme and Phyzyme were obtained from a local feed mill (CV Unggas Nusa Timor, Kupang, NTT); while Allzyme SSF -E product was provided by Alltech Indonesia, 18 Office Park, $25^{\text {th }}$ Floor, Jakarta. Avizyme product contains amylase $(800 \mathrm{U} / \mathrm{g})$, protease $(8000 \mathrm{U} / \mathrm{g})$, xylanase $(600 \mathrm{U} / \mathrm{g})$; while, Phyzyme contains phytase (5000 FTU/g). Allzyme SSF-E product contains seven enzymes that work syner- 
Table 1. Experimental Diets for Starter Birds (0 to 21 day).

\begin{tabular}{|c|c|c|c|c|}
\hline \multirow{2}{*}{ Feed Ingredients } & $(\mathrm{P} 0)$ & $(\mathrm{P} 1)$ & $(\mathrm{P} 2)$ & (P3) \\
\hline & \multicolumn{4}{|c|}{ 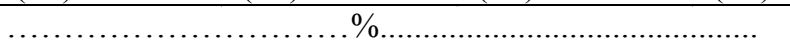 } \\
\hline Corn & 53.43 & 53.28 & 53.38 & 53.43 \\
\hline Rice Bran & - & - & - & - \\
\hline Sago & - & - & - & - \\
\hline Soybean meal & 32.00 & 32.00 & 32.00 & 32.00 \\
\hline Meat and Bone Meal & 5.00 & 5.00 & 5.00 & 5.00 \\
\hline Fish meal & 2.50 & 2.50 & 2.50 & 2.50 \\
\hline Vegetable oil & 5.00 & 5.00 & 5.00 & 5.00 \\
\hline L-Lysine $\mathrm{HCl}, 99 \%$ & 0.20 & 0.20 & 0.20 & 0.20 \\
\hline DL-Methionine & 0.30 & 0.30 & 0.30 & 0.30 \\
\hline Limestone feed grade (powder) & 5.00 & 5.00 & 5.00 & 5.00 \\
\hline Dicalcium phosphate Ca22/P18 & 0.40 & 0.40 & 0.40 & 0.40 \\
\hline Salt & 0.25 & 0.25 & 0.25 & 0.25 \\
\hline Sodium bicarbonate & 0.12 & 0.12 & 0.12 & 0.12 \\
\hline Vitamin dan Mineral Premix* & 0.30 & 0.30 & 0.30 & 0.30 \\
\hline Avizyme** & - & 0.10 & - & - \\
\hline Phyzyme** & 0 & 0.05 & - & - \\
\hline $\begin{array}{l}\text { Synbiotics Probio } \mathrm{FM}^{\mathrm{PLUS}} \text { (40 } \\
\mathrm{mL} / \mathrm{L} \text { drinking water) }\end{array}$ & - & - & - & + \\
\hline Allzyme SSF-E**** & - & - & 0.05 & - \\
\hline Total & 100 & 100 & 100 & 100 \\
\hline \multicolumn{5}{|l|}{$\begin{array}{l}\text { Nutrient Composistion } \\
\text { (Calculated, as fed) }\end{array}$} \\
\hline AME (Kcal/kg) & 2,904 & 2,900 & 2,904 & 2,904 \\
\hline Crude Protein $(\mathrm{g} / \mathrm{kg})$ & 230 & 230 & 230 & 230 \\
\hline Crude Fiber (g/kg) & 18.12 & 18.07 & 18.10 & 18.12 \\
\hline Lysine $(\mathrm{g} / \mathrm{kg})$ & 13.8 & 13.8 & 13.8 & 13.8 \\
\hline Met + Cys (g/kg) & 9.3 & 9.3 & 9.3 & 9.3 \\
\hline $\mathrm{Ca}(\mathrm{g} / \mathrm{kg})$ & 9.3 & 9.3 & 9.3 & 9.3 \\
\hline Av $P(g / k g)$ & 4.6 & 4.6 & 4.6 & 4.6 \\
\hline \multicolumn{5}{|c|}{$\begin{array}{l}\text { *)Top Mix: Every } 10 \mathrm{~kg} \text { contain } 12.000 .000 \mathrm{IU} \text { vitamin A, } 2.000 .000 \mathrm{IU} \text { vitamin D3, } 8.000 \mathrm{IU} \text { vitamin E, vitamin } \\
\text { K3 } 2.000 \mathrm{mg} \text {, vitamin B1 } 2000 \mathrm{mg} \text {, vitamin B2 } 5.000 \mathrm{mg} \text {, vitamin B12 } 12.000 .000 \mu \mathrm{g} \text {, vitamin C } 25.000 \mathrm{mg} \text {, } \\
\text { Calcium-D-panthotenate } 6000 \mathrm{mg} \text {, choline chloride } 10.000 \mathrm{mg} \text {, niacin } 40.000 \mathrm{mg} \text {, methionine } 30.000 \mathrm{mg} \text {, lysine } \\
30.000 \mathrm{mg} \text {, mangan } 120.000 \mathrm{mg} \text {, Fe } 20.000 \mathrm{mg} \text {, iodine } 200 \mathrm{mg} \text {, zink } 100.000 \mathrm{mg} \text {, cobalt } 200 \mathrm{mg} \text {, copper } 4.000 \\
\text { mg, santoquin (antioxidant) } 10.000 \mathrm{mg} \text {. ** Supplied by local feedmill; *** Supplied by State Polytechnic of } \\
\text { Agriculture; *** Supplied Alltech Ltd, Indonesia }\end{array}$} \\
\hline
\end{tabular}

gistically, namely amylase, protease, $\beta$ glucanase, cellulase, pectinase, xylanase, and phytase. The level of Allzyme SSF-E used was $0.05 \%$; the inclusion level of Avizyme and Phyzyme was 0.10 and $0.05 \%$, respectively. The choice of the enzymes and Synbiotics levels applied in the diets was based on the result of the previous study (Nalle et al., 2020).

\section{Excreta Collection for AME and Nutrient Di- gestibility Determination}

Apparent metabolizable energy and nutrient digestibility were determined through the measurement of feed intake and excreta output. Total excreta collection was conducted according to Nalle et al. (2020). A tray was put underneath the cage on day 31 , and the collection of excreta was conducted during four consecutive days (day 32 to day 35). The excreta should be free from feathers, feed residues, and other contaminants before being collected. The excreta was then put in the freezer (Modena, $-20^{\circ} \mathrm{C}$ ) to avoid the fermentation process. Feed intake was determined and recorded quantitatively per cage during the period of excreta collection (days 32 to 35 ). The excreta sample from each cage was defrosted at room temperature, pooled, homogenized, subsampled, and dried in Jouan oven at $60^{\circ} \mathrm{C}$. The dried excreta samples and experimental diets were ground in a sample mill (Foss CT $193 \mathrm{Cy}$ - 
Continued... Table 1. Experimental Diets for Starter Birds (0 to 21 day).

\begin{tabular}{|c|c|c|c|c|}
\hline \multirow{2}{*}{ Feed Ingredients } & $(\mathrm{P} 4)$ & (P5) & (P6) & $(\mathrm{P} 7)$ \\
\hline & \multicolumn{4}{|c|}{ 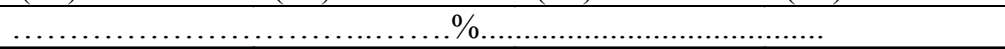 } \\
\hline Corn & 35.00 & 34.85 & 34.95 & 35.00 \\
\hline Rice Bran & 5.00 & 5.00 & 5.00 & 5.00 \\
\hline Sago & 10.00 & 10.00 & 10.00 & 10.00 \\
\hline Soybean meal & 34.63 & 34.63 & 34.63 & 34.63 \\
\hline Meat and Bone Meal & 5.00 & 5.00 & 5.00 & 5.00 \\
\hline Fish meal & 2.50 & 2.50 & 2.50 & 2.50 \\
\hline Vegetable oil & 6.00 & 6.00 & 6.00 & 6.00 \\
\hline L-Lysine $\mathrm{HCl}, 99 \%$ & 0.13 & 0.13 & 0.13 & 0.13 \\
\hline DL-Methionine & 0.22 & 0.22 & 0.22 & 0.22 \\
\hline $\begin{array}{l}\text { Limestone feed grade } \\
\text { (powder) }\end{array}$ & 0.37 & 0.37 & 0.37 & 0.37 \\
\hline \multicolumn{5}{|l|}{$\mathrm{Ca} 22 / \mathrm{P} 18$} \\
\hline Salt & 0.25 & 0.25 & 0.25 & 0.25 \\
\hline Sodium bicarbonate & 0.12 & 0.12 & 0.12 & 0.12 \\
\hline $\begin{array}{l}\text { Vitamin dan Mineral } \\
\text { Premix* }\end{array}$ & 0.30 & 0.30 & 0.30 & 0.30 \\
\hline Avizyme** & - & 0.10 & - & - \\
\hline Phyzyme** & - & 0.05 & - & - \\
\hline $\begin{array}{l}\text { Synbiotics Probio } \\
\mathrm{FM}^{\text {PLUS }}(40 \mathrm{~mL} / \mathrm{L} \\
\text { drinking water })^{* * *}\end{array}$ & - & - & - & + \\
\hline Allzyme SSF-E**** & - & - & 0.05 & - \\
\hline Total & 100 & 100 & 100 & 100 \\
\hline \multicolumn{5}{|l|}{$\begin{array}{l}\text { Nutrient Composistion } \\
\text { (Calculated, as fed) }\end{array}$} \\
\hline AME (Kcal/kg) & 2,835 & 2,830 & 2,833 & 2,835 \\
\hline Crude Protein $(\mathrm{g} / \mathrm{kg})$ & 230 & 230 & 230 & 230 \\
\hline Crude Fiber (g/kg) & 24.04 & 24.04 & 24.04 & 24.04 \\
\hline Lysine $(\mathrm{g} / \mathrm{kg})$ & 13.9 & 13.9 & 13.9 & 13.9 \\
\hline Met + Cys (g/kg) & 9.4 & 9.3 & 9.4 & 9.4 \\
\hline $\mathrm{Ca}(\mathrm{g} / \mathrm{kg})$ & 9.3 & 9.3 & 9.3 & 9.3 \\
\hline $\operatorname{Av} P(g / k g)$ & 4.6 & 4.6 & 4.6 & 4.6 \\
\hline \multicolumn{5}{|c|}{$\begin{array}{l}\text { *)Top Mix: Every } 10 \mathrm{~kg} \text { contain } 12.000 .000 \mathrm{IU} \text { vitamin A, } 2.000 .000 \mathrm{IU} \text { vitamin D3, } 8.000 \mathrm{IU} \text { vitamin E, } \\
\text { vitamin K3 } 2.000 \mathrm{mg} \text {, vitamin B1 } 2000 \mathrm{mg} \text {, vitamin B2 } 5.000 \mathrm{mg} \text {, vitamin B12 } 12.000 .000 \mu \mathrm{g} \text {, vitamin C } \\
25.000 \mathrm{mg} \text {, Calcium-D-panthotenate } 6000 \mathrm{mg} \text {, choline chloride } 10.000 \mathrm{mg} \text {, niacin } 40.000 \mathrm{mg} \text {, methionine } \\
30.000 \mathrm{mg} \text {, lysine } 30.000 \mathrm{mg} \text {, mangan } 120.000 \mathrm{mg} \text {, Fe } 20.000 \mathrm{mg} \text {, iodine } 200 \mathrm{mg} \text {, zink } 100.000 \mathrm{mg} \text {, cobalt } \\
200 \mathrm{mg} \text {, copper } 4.000 \mathrm{mg} \text {, santoquin (antioxidant) } 10.000 \mathrm{mg} \text {. ** Supplied by local feedmill; *** Supplied by } \\
\text { State Polytechnic of Agriculture; *** Supplied Alltech Ltd, Indonesia }\end{array}$} \\
\hline
\end{tabular}

clotec, $0.5 \mathrm{~mm}$ screen size), packed, labeled, and sent to the laboratory for chemical analysis (dry matter, gross energy, nitrogen, starch, neutral detergent fiber, calcium, and phosphor).

\section{Chemical Analysis}

Dry matter. The dry matter content of experimental diets and excreta was determined by using AOAC method no. 930.15 (AOAC, 2005). Determination of the dry matter content of the sample was conducted with the following procedure: 1) two glass dishes fitted with lids were precisely weighed. 2) $2 \pm 0.01 \mathrm{~g}$ of sample was placed in each dish and rapidly reweighed the dish with the lid. The lid was put under each dish (with sample) and oven-dried $\left(105^{\circ} \mathrm{C}\right)$ overnight $(12 \mathrm{~h})$. The dish was covered with the lid before removing it from the oven, then immediately cooled down in the desiccators and reweighed the dishes (with lid and dried sample).

Nitrogen. The nitrogen content of experimental diets and excreta was analyzed using AOAC 2001.1 (AOAC, 2005) in three distinct 
Table 2. Experimental Diets for Growing Birds (22 to 35 day)

\begin{tabular}{|c|c|c|c|c|}
\hline \multirow[t]{2}{*}{ Feed Ingredients } & (P0) & (P1) & $(\mathrm{P} 2)$ & (P3) \\
\hline & \multicolumn{4}{|c|}{ 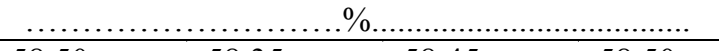 } \\
\hline Corn & 58.50 & 58,35 & 58,45 & 58.50 \\
\hline Rice Bran & - & - & - & - \\
\hline Sago & - & - & - & - \\
\hline Soybean meal & 27.33 & 27.33 & 27.33 & 27.33 \\
\hline Meat and Bone Meal & 5.00 & 5.00 & 5.00 & 5.00 \\
\hline Fish meal & 2.50 & 2.50 & 2.50 & 2.50 \\
\hline Vegetable oil & 4.50 & 4.50 & 4.50 & 4.50 \\
\hline L-Lysine $\mathrm{HCl}, 99 \%$ & 0.20 & 0.20 & 0.20 & 0.20 \\
\hline DL-Methionine & 0.30 & 0.30 & 0.30 & 0.30 \\
\hline Limestone feed grade (powder) & 0.50 & 0.50 & 0.50 & 0.50 \\
\hline Dicalcium phosphate Ca22/P18 & 0.50 & 0.50 & 0.50 & 0.50 \\
\hline Salt & 0.25 & 0.25 & 0.25 & 0.25 \\
\hline Sodium bicarbonate & 0.12 & 0.12 & 0.12 & 0.12 \\
\hline Vitamin dan Mineral Premix* & 0.30 & 0.30 & 0.30 & 0.30 \\
\hline Avizyme** & - & 0.10 & - & - \\
\hline Phyzyme** & - & 0.05 & - & - \\
\hline $\begin{array}{l}\text { Synbiotics Probio FM }{ }^{\mathrm{PLUS}}(40 \mathrm{~mL} / \mathrm{L} \\
\text { drinking water })^{* * *}\end{array}$ & - & - & - & + \\
\hline Allzyme SSF-E**** & - & - & 0.05 & \\
\hline Total & 100 & 100 & 100 & 100 \\
\hline \multicolumn{5}{|c|}{ Nutrient Composistion (Calculated, as fed) } \\
\hline AME (Kcal/kg) & 2,903 & 2,898 & 2,836 & 2,903 \\
\hline Crude Protein $(\mathrm{g} / \mathrm{kg})$ & 214 & 214 & 214 & 214 \\
\hline Crude Fiber $(\mathrm{g} / \mathrm{kg})$ & 19.57 & 19.53 & 19.55 & 19.57 \\
\hline Lysine $(\mathrm{g} / \mathrm{kg})$ & 12.6 & 12.6 & 12.6 & 12.6 \\
\hline Met + Cys $(\mathrm{g} / \mathrm{kg})$ & 8.7 & 8.7 & 8.8 & 8.7 \\
\hline $\mathrm{Ca}(\mathrm{g} / \mathrm{kg})$ & 9.3 & 9.3 & 9.3 & 9.3 \\
\hline $\operatorname{Av} P(g / k g)$ & 4.3 & 4.4 & 4.4 & 4.3 \\
\hline \multicolumn{5}{|c|}{ Nutrient Composistion (Laboratory analysis, as fed) } \\
\hline Gross Energy (Kcal/kg) & 3310 & 3488 & 3270 & 3291 \\
\hline Crude Protein (g/kg) & 202 & 207 & 216 & 202 \\
\hline Crude Fiber $(\mathrm{g} / \mathrm{kg})$ & 29.5 & 28.2 & 29.2 & 29.5 \\
\hline Neutral Detergent Fiber (g/kg) & 205 & 213 & 245 & 205 \\
\hline Total Phosphor $(\mathrm{g} / \mathrm{kg})$ & 4.6 & 4.7 & 4.8 & 4.6 \\
\hline \multicolumn{5}{|c|}{$\begin{array}{l}\text { *)Top Mix: Every } 10 \mathrm{~kg} \text { contain } 12.000 .000 \mathrm{IU} \text { vitamin A, } 2.000 .000 \mathrm{IU} \text { vitamin D3, } 8.000 \mathrm{IU} \text { vitamin E, } \\
\text { vitamin K3 } 2.000 \mathrm{mg} \text {, vitamin B1 } 2000 \mathrm{mg} \text {, vitamin B2 } 5.000 \mathrm{mg} \text {, vitamin B12 } 12.000 .000 \mu \mathrm{gg} \text {, vitamin C } \\
25.000 \mathrm{mg} \text {, Calcium-D-panthotenate } 6000 \mathrm{mg} \text {, choline chloride } 10.000 \mathrm{mg} \text {, niacin } 40.000 \mathrm{mg} \text {, methionine } \\
30.000 \mathrm{mg} \text {, lysine } 30.000 \mathrm{mg} \text {, mangan } 120.000 \mathrm{mg} \text {, Fe } 20.000 \mathrm{mg} \text {, iodine } 200 \mathrm{mg} \text {, zink } 100.000 \mathrm{mg} \text {, cobalt } \\
200 \mathrm{mg} \text {, copper } 4.000 \mathrm{mg} \text {, santoquin (antioxidant) } 10.000 \mathrm{mg} \text {. ** Supplied by local feedmill; *** Supplied by } \\
\text { State Polytechnic of Agriculture Kupang; **** Supplied by Alltech Ltd, Indonesia }\end{array}$} \\
\hline
\end{tabular}

steps which were digestion (BÜTCHI SpeedDigester K-439), distillation (BÜTCHI Distillation Unit K-355), and titration. A) Digestion process: A total of $1 \pm 0.01 \mathrm{~g}$ sample was weighed accurately and placed into a Kjeldahl tube, then two Kjeldahl tablets and 15 $\mathrm{mL} \mathrm{H}_{2} \mathrm{SO}_{4}$ were added. The tube was placed in BÜTCHI Block Digestor Unit $\left(420^{\circ} \mathrm{C}\right)$ for about 45 to 60 minutes. Blank digestion was carried out at the same time. Distilled water was added to each tube and shaken gently. B)
Distillation process: The Distillation Unit was pre-heated for 3 minutes, and the digestion tube was connected in distilled position. The receiver conical flask was filled with $25 \mathrm{~mL}$ boric acid solution $\left(4 \% \mathrm{H}_{3} \mathrm{O}_{3}\right)$, and one to two drops of methyl red solution was added. The flask was placed in the collection position. The $\mathrm{H}_{2} \mathrm{O}$ button was pressed for the automatic addition of 50 $\mathrm{mL}$ Aquadest (distilled water). Then, the Start button was pressed to run the distillation process for about 5 minutes. The conical flask and 
Continued...Table 2. Experimental Diets for Growing Birds (22 to 35 day)

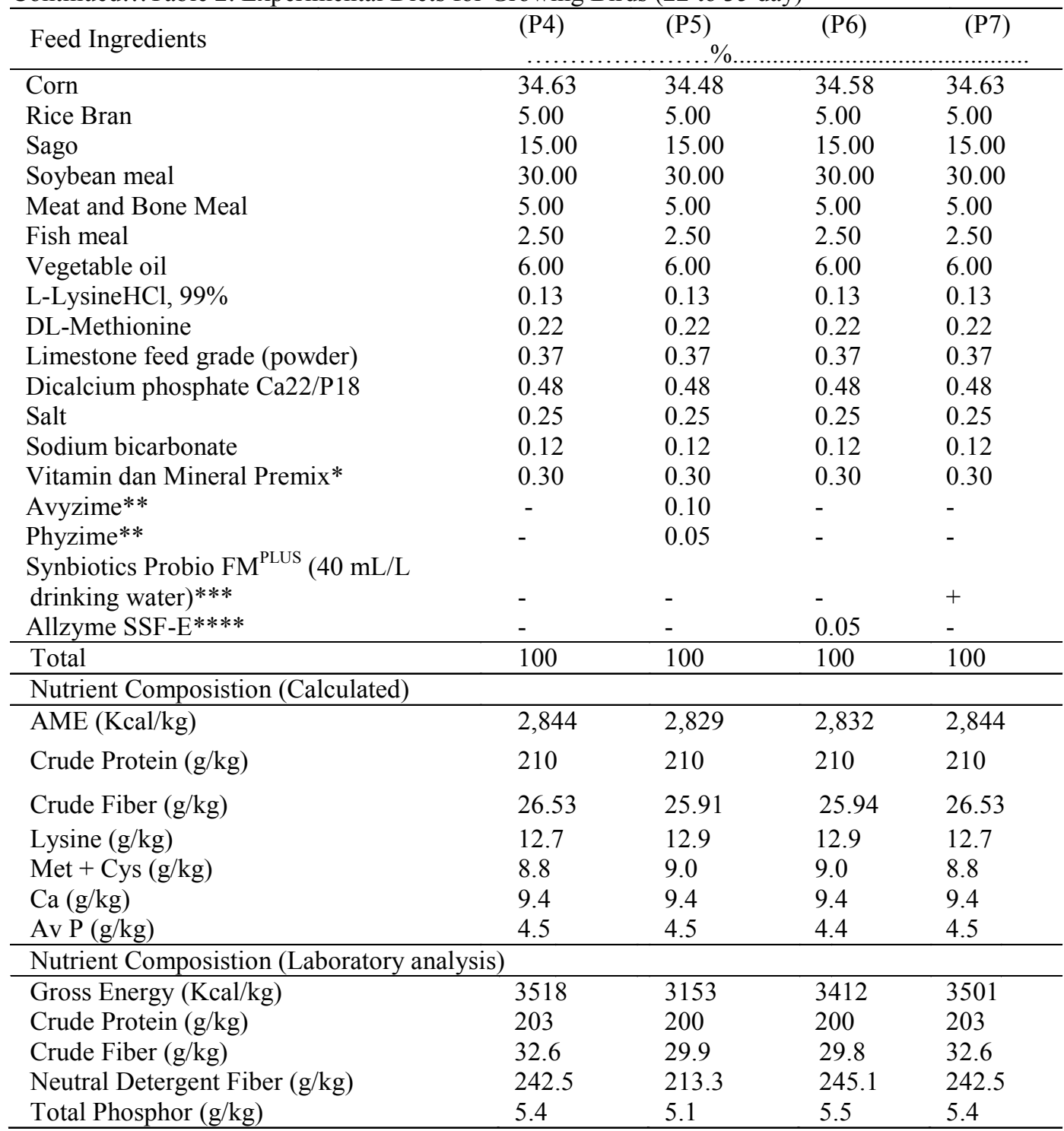

*)Top Mix: Every $10 \mathrm{~kg}$ contain 12.000.000 IU vitamin A, 2.000.000 IU vitamin D3, 8.000 IU vitamin E, vitamin K3 $2.000 \mathrm{mg}$, vitamin B1 $2000 \mathrm{mg}$, vitamin B2 $5.000 \mathrm{mg}$, vitamin B12 $12.000 .000 \mu \mathrm{g}$, vitamin C $25.000 \mathrm{mg}$, Calcium-D-panthotenate $6000 \mathrm{mg}$, choline chloride $10.000 \mathrm{mg}$, niacin $40.000 \mathrm{mg}$, methionine $30.000 \mathrm{mg}$, lysine $30.000 \mathrm{mg}$, mangan $120.000 \mathrm{mg}$, Fe $20.000 \mathrm{mg}$, iodine $200 \mathrm{mg}$, zink $100.000 \mathrm{mg}$, cobalt $200 \mathrm{mg}$, copper 4.000 $\mathrm{mg}$, santoquin (antioxidant) $10.000 \mathrm{mg}$. ** Supplied by local feedmill; *** Supplied by State Polytechnic of Agriculture Kupang; **** Supplied Alltech Ltd, Indonesia

the digestion tube were removed. C) Titration process: The sample in the conical flask was titrated with $0.1 \mathrm{~N} \mathrm{HCl}$ to a gray-mauve endpoint.

Neutral detergent fiber (NDF). The AOAC 942.5 (Van Soest Method, AOAC, 2005) was used to determine NDF content of experimental diets and excreta. The neutral detergent fiber (NDF) analysis was conducted as follows: The sample was added with an NDF solution, and then digested, filtered (with sintered glass funnel, and a vacuum), rinsed with acetone, oven -dried $\left(105^{\circ} \mathrm{C}\right)$ overnight, cooled in a desiccator for about 30 minutes, and weighed.

Starch. The starch content of experimental diets and excreta was analyzed using the Luff Schrool titration method (SNI 01-28911992). The starch analysis procedure was conducted as follows: weighed approximately $5 \mathrm{~g}$ of the sample into the $500 \mathrm{~mL}$ Erlenmeyer, then added $200 \mathrm{~mL}$ of $3 \% \mathrm{HCl}$ solution, and boiled for 3 hours. Cooled and neutralized with 30\% 
$\mathrm{NaOH}$ solution, and added a little $3 \% \mathrm{CaCO}_{3}$ so that the solution was slightly acidic. The contents were transferred into a $500 \mathrm{~mL}$ volumetric flask and squeezed, then filtered. As much as $10 \mathrm{~mL}$ of filtrate was pipette into the $500 \mathrm{~mL}$ Erlenmeyer, $25 \mathrm{~mL}$ of Luff Schrool solution was added with a pipette. A few boiling bolts and $15 \mathrm{~mL}$ of distilled water were added to the mixture. The mixture was heated on a steady flame, to bring the solution to a boil within 3 minutes; this was then simmered for exactly 10 minutes. This solution was then quickly cooled in a tub of ice. After chilling, slowly add $15 \mathrm{~mL}$ of KI $20 \%$ solution and 25 $\mathrm{mL}$ of $25 \% \mathrm{H}_{2} \mathrm{SO}_{4}$. Then, immediately titrate with $0.1 \mathrm{~N}$ sodium thiosulphate solution. A blank was also analyzed at the same time.

Gross energy. The gross energy (GE) content of samples was determined using an automatic Bomb Calorimeter (IKA C2000) based on the method described by Nalle et al. (2021) as follows: weighed 1 gram of the ground sample and placed in a dish. As many as $10 \mathrm{~cm}$ threads were tied to the fuse wire and positioned under the ground sample. The heat bomb was closed and put in the bomb cylinder. Oxygen $\left(\mathrm{O}_{2}\right)$ was added to the bomb at a flow rate of approximately $30 \mathrm{ATM} / \mathrm{BAR}$. As much as $2 \mathrm{~L}$ of distilled water was added to the bucket. The bomb was put in the bucket, the ignition fire was connected, the drive ring was attached, and the stirrer turned on. The digital temperature machine was turned on and left for 5 minutes for the temperature to stabilize. The initial temperature was recorded, and then the bombing was carried out by pressing the bomb button and waited for about 5 to 10 seconds for the temperature to rise. The final temperature reading was recorded when the temperature rises and then the drops.

Phosphor. Determination of phosphor (P) content of experimental diets and excreta used a Spectrophotometer. The analytical procedure of $\mathrm{P}$ was as follows: the sample was weighed and then ignited $\left(550^{\circ} \mathrm{C}\right)$ for 3 hours, then digested using an acid solution, dissolved into a measuring flask, pipette, and measured with a spectro- photometer at a wavelength of $400 \mathrm{~nm}$.

\section{Experimental Design}

The experiment was designed using a $2 \mathrm{x}$ 4 factorial completed randomized design (Gomez and Gomez, 1984). The first main factor was the type of diet (corn-SBM, and corn-rice bran-sago-SBM), and the second factor was feed additives (control, Avizyme-Phyzyme, Allzyme SSF-E, and Synbiotics Probio FMplus). Thus, there were eight treatment combinations with three replications (11 birds/replication) per treatment. The birds were fed starter (mash form, 0 21 day) and grower (pellet form, 22-35 day) diets (iso-nitrogenic and iso-caloric). Drinking water was available for 24 hours (with or without synbioticss). The treatment diets were as follows:

P0 corn-SBM

P1 corn-SBM + Avizyme $0.10 \%$ and Phyzyme $0.05 \%$

P2 corn-SBM + Allzyme SSF $0.05 \%$

P3 corn-SBM + Synbiotics Probio FMplus $40 \mathrm{~mL} / \mathrm{L}$ drinking water

P4 corn-sago-rice bran-SBM

P5 corn-sago- rice bran-SBM + Avizyme $0.10 \%$ and Phyzyme $0.05 \%$

P6 corn-sago- rice bran-SBM + Allzyme SSF $0.05 \%$

P7 corn-sago- rice bran-SBM + Synbiotics Probio FMplus $40 \mathrm{~mL} / \mathrm{L}$ drinking water

\section{Data Collection}

The initial body weight of broiler chicks was measured using a digital scale on day 0 . Body weights and feed intake data were documented on a pen basis on days $7,14,21,28$, and $35)$. Mortality data were recorded every day and used to correct the calculation of the feed conversion ratio (FCR). The excreta of birds was visually scored on day 35 . The gut size was measured on day 35 . 


\section{Calculations}

1. Growth performance: The body weight gain and feed intake were calculated weekly. The mortality of birds and the weight of dead birds were recorded daily. The mortality data obtained were used to correct the calculation of the feed conversion ratio (FCR). The FCR was calculated using formula (Nalle et al., 2011):

2. Digestive tract size: The measurement of digestive tract size was conducted based on the method described by Nalle et al. (2011). On day 35, six birds from each treatment, with individual body weight closest to the mean weight of the pen, were selected and euthanized by cervical dislocation. The mesentery of each segment of the digestive tract was removed before measuring their absolute length $(\mathrm{cm})$ and absolute (full and empty) weight $( \pm 0.1 \mathrm{~g})$. The absolute size of each segment was converted to the relative length $(\mathrm{cm} / \mathrm{kg} \mathrm{BW})$ and weight $(\mathrm{g} / \mathrm{kg} \mathrm{BW})$ using the body weight data of each bird.

3. Total tract nutrient digestibility coefficient was calculated according to the formula of Abdollahi et al. (2016).

4. The calculation of apparent metabolizable energy (AME) values was as follows (Nalle et al., 2012).

Correction for zero nitrogen retention was made using a factor of $36.54 \mathrm{~kJ}$ per gram nitrogen retained in the body (Hill and Anderson, 1958).

\section{Statistical Analysis}

Data obtained from the present study were calculated using a two-way analysis of variance (ANOVA) according to the General Linear Model procedure of SAS (University Edition, SAS Institute). The performance, apparent metabolizable energy, and nutrient digestibility data used the cage as the experimental unit. The significant differences between treatments were determined at $\mathrm{P}<0.05$. The Fisher's Least Significant Difference Test (LSD) was conducted to differentiate the difference.

\section{RESULTS}

\section{Growth Performance of Broilers}

Table 3 represents the effect of treatment diets on the growth performance of birds during the starter phase. The type of diet (TD) $x$ feed additives (FA) interaction was found to be significant $(\mathrm{P}<0.05$ to 0.001$)$ on feed intake (FI) and body weight gain (BWG), but was not significant $(\mathrm{P}>0.05)$ on feed conversion ratio (FCR). The birds fed on the corn-SBM diet without feed additives had similar $(\mathrm{P}>0.05)$ FI and BWG with those who were fed corn-SBM diet supplemented with Synbiotics Probio FMplus, but they were higher $(\mathrm{P}<0.05)$ than those who were given corn-SBM diet supplemented with complex (Allzyme SSF-E) and multi-enzymes (Table 3). The birds fed rice bran-sago- diets without feed additives (control) has similar $(\mathrm{P}>0.05)$ FI, BWG and FCR with the group of birds who were fed rice bran-sago diets supplemented with Avizyme+Phyzyme, Allzyme SSFE, and synbiotics (Table 3).

Regarding the main effects, FA had an effect $(\mathrm{P}<0.05)$ on bird's FCR only on day 21 . The birds fed on control diet had comparable $(\mathrm{P}>0.05)$ FCR with those who were fed multi enzymes (Avizyme + Phyzyme), Synbiotics; but it was lower $(\mathrm{P}<0.05)$ than that of complex enzyme (Allzyme SSF-E) during 21d of the experiment.

Table 4 depicts the effect of treatment diets on the growth performance of birds during the grower phase. During the grower phase, TD $x$ FA interaction significantly affected $(\mathrm{P}<0.001)$ FI, BWG, and FCR of broilers (Table 4). The birds fed on corn-SBM diets without FA (control) had comparable ( $\mathrm{P}>0.05)$ FI with those who were given corn-SBM diets supplemented with Synbiotics. FI, and BWG of birds fed cornSBM diets supplemented with Allzyme SSF-E was lower $(\mathrm{P}<0.05)$ than the other treatment diets. The group of birds fed on corn-SBM diets supplemented with Allzyme SSF-E had the highest $(\mathrm{P}<0.05)$ FCR. The FCR of birds fed cornSBM diets supplemented with Synbiotics was comparable $(\mathrm{P}>0.05)$ to that of control group, 


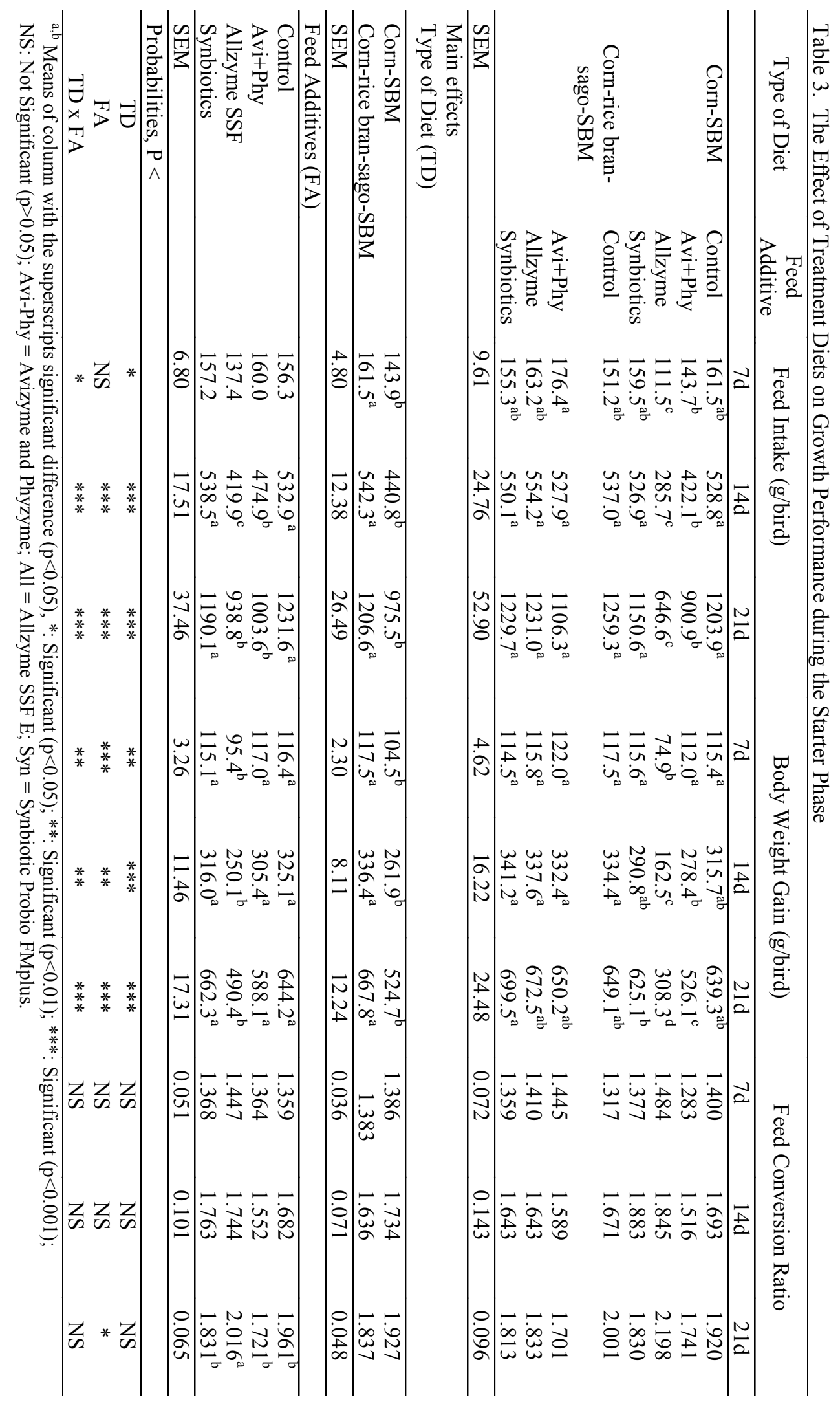




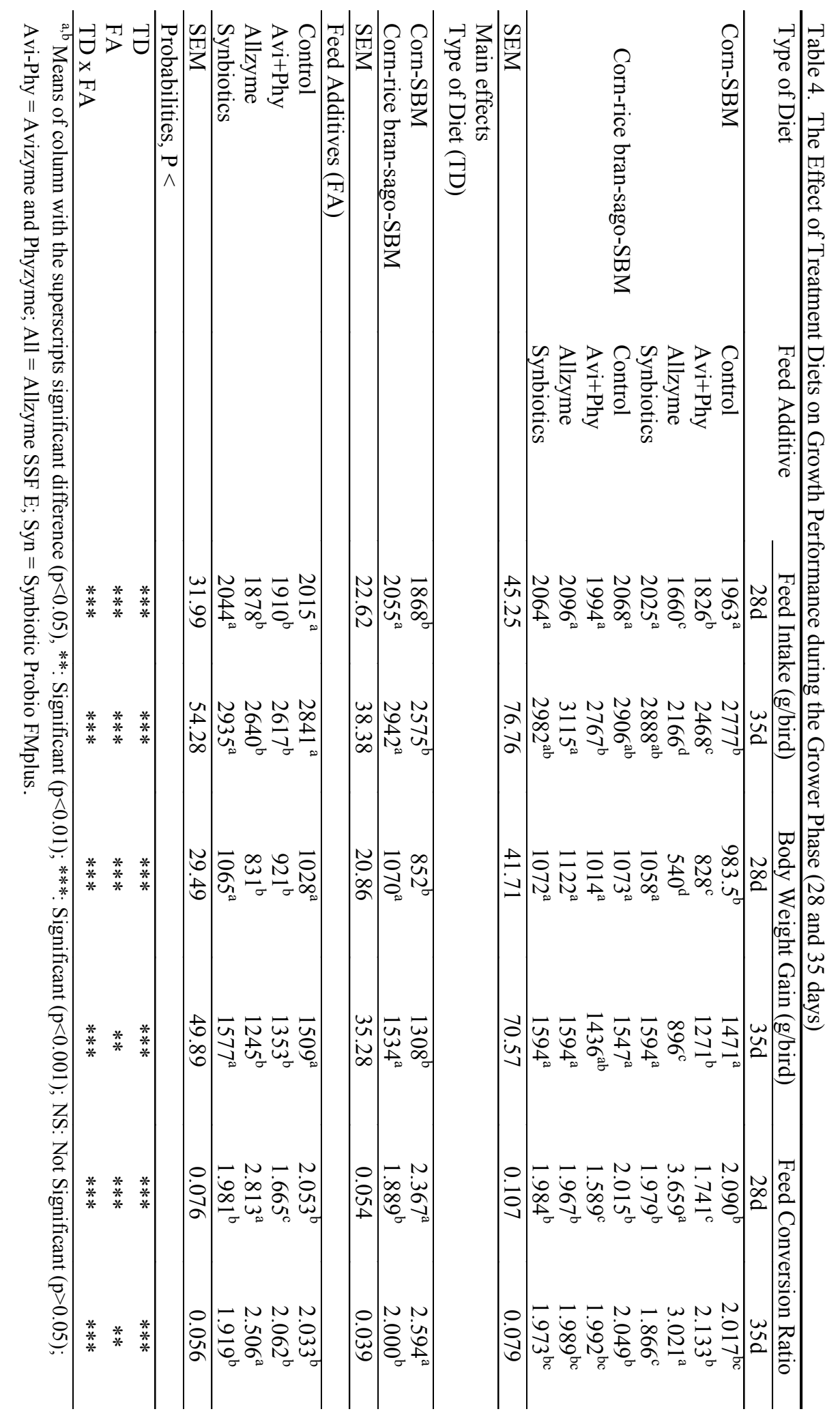


but it was lower than the enzyme groups.

On days 28 and 35, the FI, and BWG of birds fed rice bran-sago diets without FA (control) were comparable ( $\mathrm{P}>0.05)$ to those who were fed the same type of diet supplemented with multi enzymes (Avizyme + Phyzyme), complex enzymes (Allzyme SSF-E), and Synbiotics. On day 35, the FI of birds fed on diets containing rice bran and sago supplemented with Allzyme SSF-E was higher $(\mathrm{P}<0.05)$ than those who were fed rice bran-sago diets supplemented with multi enzymes; but it was comparable $(\mathrm{P}>0.05)$ to those who were fed rice bran-sago diet without feed additive, and with Synbiotics. On day 28, the FCR of birds fed on diets containing rice bran and sago without FA was simi$\operatorname{lar}(\mathrm{P}>0.05)$ to those who were fed the same type of diet supplemented with Allzyme SSF-E, and Synbiotics, but it was higher $(\mathrm{P}<0.05)$ than those who were fed rice bran-sago diet supplemented with Avizyme + Phyzyme.

The birds fed on rice bran-sago diets had higher $(\mathrm{P}<0.05) \mathrm{FI}$ and $\mathrm{BWG}$ compared to those who were fed corn-SBM diets during the starter and grower phases. The FCR of birds fed on rice bran-sago diets was lower $(\mathrm{P}<0.05)$ than those who were fed corn-SBM diets during the grower phase.

\section{Digestive Tract Development of Broilers}

Table 5 depicts the digestive tract development of broilers fed different treatment diets. Type of diet (TD) $x$ feed additives (FA) interaction was significant $(\mathrm{P}<0.05$ to 0.01$)$ on liver weight, proventriculus and gizzard length, and caecum digesta weight of birds during the experiment. The group of birds fed on a corn-SBM diet supplemented with Allzyme SSF-E had higher $(\mathrm{P}<0.05)$ liver weight, proventriculus, gizzard, and caecum length compared to the other treatment diets. The length of proventriculus, gizzard, and caecum relative to the body weight of birds fed corn-SBM diets without feed additives were similar $(\mathrm{P}>0.05)$ to those who were fed corn-SBM diet supplemented with Synbiotics, but it was lower $(p<0.05)$ than that of enzyme groups. No significant difference $(\mathrm{P}>0.05)$ was observed in proventriculus, gizzard and caecum relative length in birds fed diets containing rice bran and sago with and without feed additives.

The type of diet (TD) affected $(\mathrm{P}<0.05$ to $0.001)$ the relative weight of liver, the relative empty weight of gizzard, the relative length of proventriculus, gizzard, and colon, and the relative digestive weight of colon of birds. The relative weight of liver and gizzard of birds fed cornSBM diet was higher $(\mathrm{P}<0.05)$ than those who were fed corn-rice bran-sago-SBM diet. The same trend was also found in the relative length of proventriculus and gizzard. The relative digestive weight of the colon of birds fed on diets containing rice bran and sago was higher $(\mathrm{P}<0.05)$ than that of the corn-SBM diet.

Except for the small intestine, feed additives (FA) did not affect $(\mathrm{P}>0.05)$ the relative weight of the spleen and pancreas, and the relative empty weight of crops, proventriculus, gizzard, caecum, and colon of birds during 35 days of the experiment (Table 6). Feed additives significantly influenced $(\mathrm{P}<0.01)$ the relative length of the proventriculus, gizzard, and small intestine of birds. Except for caecum digesta weight, the main effect of FA did not affect $(\mathrm{P}>0.05)$ the relative digesta content of the gastrointestinal tract of birds during the trial.

\section{Nutrient Digestibility and the apparent Me- tabolizable Energy and of Broilers}

Table 6 describes the effect of treatment diets on the total tract of nutrient digestibility coefficient and the apparent metabolizable energy. The type of diet $\mathrm{x}$ feed additive interaction was not significant $(\mathrm{P}>0.05)$ on nutrient digestibility coefficient, but it was significant $(\mathrm{P}<0.05)$ for AME and AMEn values (Table 6). The AME and AMEn values of birds fed corn-SBM diet were comparable $(\mathrm{P}>0.05)$ to those who were fed corn-SBM diets supplemented with multi enzymes and synbiotics, but they were lower $(\mathrm{P}<0.05)$ than those who were fed complex enzymes (Allzyme SSF-E). The AME value of birds fed a corn-SBM diet supplemented with Allzyme SSF-E was similar $(\mathrm{P}>0.05)$ to the multi 
-enzymes (Avizyme + Phyzyme) group. The AMEn value of the corn-SBM diet supplemented with Allzyme SSF-E was similar $(\mathrm{P}>0.05)$ to that of corn-SBM diets without FA and corn-SBM with multi-enzymes (Avizyme + Phyzyme).

The AME and AMEn values of birds fed on diets containing rice bran and sago without FA (control) were similar $(\mathrm{P}>0.05)$ to those who were fed on diets containing rice bran and sago supplemented with different FA. The birds fed rice bran-sago diets supplemented with multi (Avizyme + Phyzyme) or complex enzymes (Allzyme SSF-E) had lower $(\mathrm{P}<0.05) \mathrm{AME}$ and AMEn values than those who were fed cornSBM diets supplemented with Allzyme SSF-E.

The type of diet did not affect $(\mathrm{P}>0.05)$, except for starch, total tract digestibility coefficient of neutral detergent fiber (NDF), and phosphor $(\mathrm{P})$, and the apparent metabolizable energy (AME), the nitrogen-corrected AME (AMEn) values. As seen in Table 6, the birds fed cornSBM diet had a higher $(\mathrm{P}<0.05)$ starch digestibility coefficient than those fed corn-rice bran-sago -SBM diet.

Regarding the main effect II (feed additives), except for the digestibility coefficient of crude protein (DCCP), total tract nutrient digestibility coefficient and the AME and AMEn values were not affected $(\mathrm{P}>0.05)$ by feed additives. Type of diet $\mathrm{x}$ feed additives interaction was not significant $(\mathrm{P}>0.05)$ for nutrient digestibility coefficients, but significant $(\mathrm{P}<0.05)$ for $\mathrm{AME}$ and AMEn values. The DCCP of birds fed Avizyme+Phyzyme, and Allzyme SSF was higher $(\mathrm{P}<0.05)$ than those who were given the control treatment (without FA).

\section{DISCUSSION}

\section{Growth Performance of Birds}

In general, the treatment combinations caused different responses in FI, BWG, and FCR of birds during the starter and grower phases. The birds fed corn-SBM diets supplemented with multi (Avizyme + Phyzyme) and complex enzymes (Allzyme SSF-E) showed a decreased FI, BWG, and feed efficiency. While the decreased
FI and BWG were not observed in the group of birds fed rice bran sago diets supplemented with different feed additives. The decreased BWG of birds in the group of birds fed corn-SBM diets supplemented with the complex (Allzyme SSF) or with multi-enzyme groups were solely due to the decrease in FI (Table 3 and 4). The decreased FI in the group of birds fed corn-SBM diets supplemented with multi and complex enzymes was probably due to the change in nutrient digestion and absorption. As seen in Table 6, the AME (13.38) and AMEn (14.28) values of corn-SBMN diets supplemented with enzymes exhibited the energy requirement of broilers according NRC (1994). As a consequence, the birds would stop eating because the energy requirement had been fulfilled. In this condition finally, the feed intake would decrease. Ferket and Garnet (2006) explained that energy diets affected feed intake. These authors also explained that the birds would stop eating when their energy requirement is achieved. Latshaw (2008) reported that animals could count metabolizable energy (ME) calorie intake and adjust feed intake to accomplish this. This nutrient uptake regulation was controlled by hormones in the Central Nervous System (CNS). Within CNS, hypothalamic neural circuits play an important role in integrating peripheral signals conveying information about energy and nutrient status, which is interpreted and used to modulate feeding behavior and energy expenditure to maintain body weight and energy stores at a set level (Richards and Proszkowiec-Weglarz, 2007).

The supplementation of Synbiotics in the group of birds fed on corn-SBM diets did not improved the growth performance of birds during the experimental periods. The similar result was also observed in group of birds fed on nonsago or sago diets supplemented with Synbiotics. The un-improvement in growth performance of birds in these treatment diets was related with the un-improvement in nutrient digestibility and energy values (Table 6). The present result agreed with Nalle et al. (2021) who reported that the addition of Synbiotics $20 \mathrm{~mL} / \mathrm{L}$ drinking 


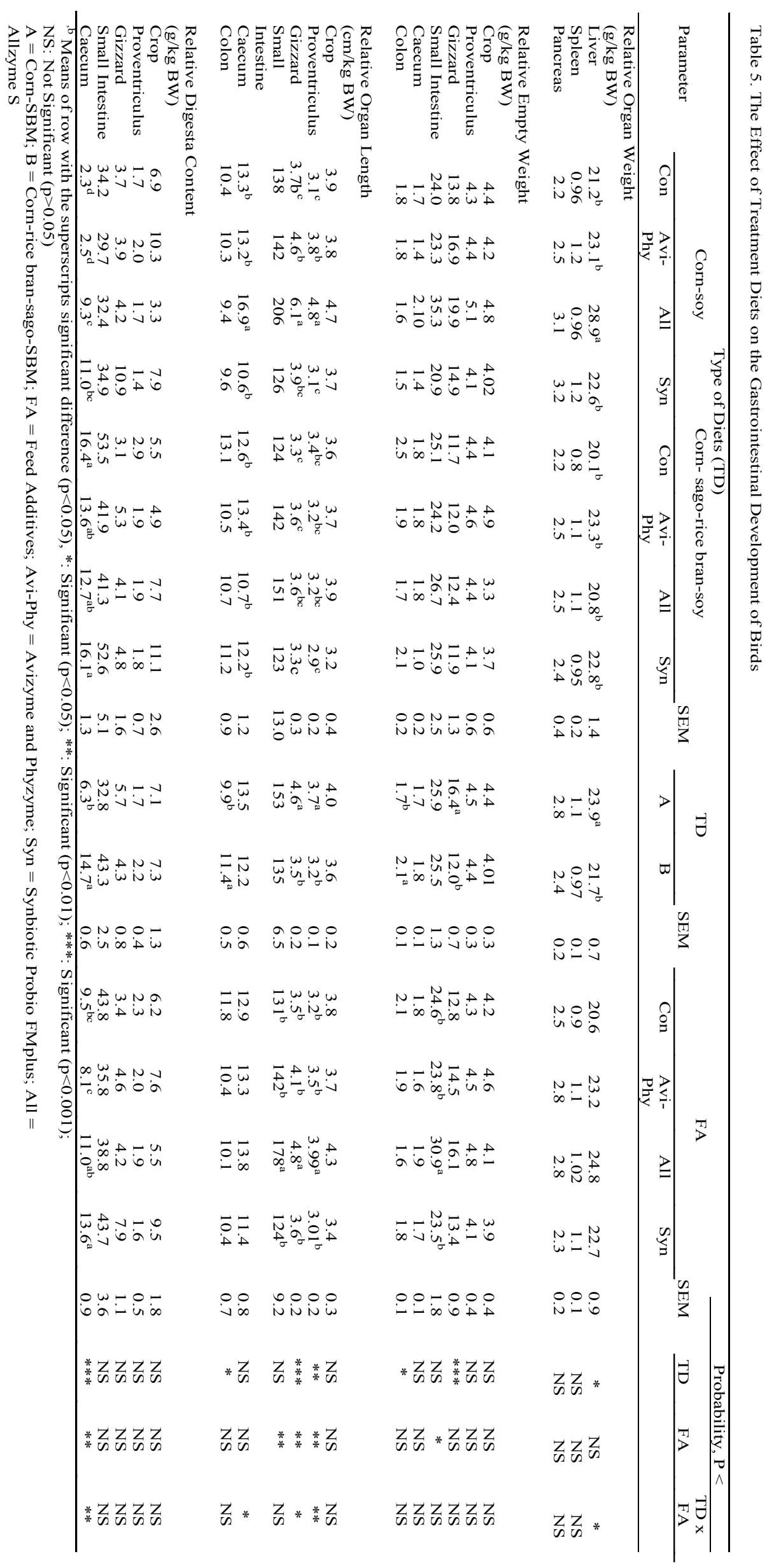


water in the group of birds fed corn-SBM or corn -sago-SBM diets did not improve the growth performance of 28 day-old birds.

The addition of complex and multienzymes in rice bran-sago diets did not ameliorate the growth performance of birds. The unimproved growth performance of birds fed rice bran -sago diets supplemented with multi and complex enzymes during the trial periods agreed with Nalle et al. (2020). The slight improvement in nutrient digestibility, and significant improvement in AME, and AMEn values observed in the group of birds fed corn-SBM diets supplemented with complex enzyme (Allzyme SSF-E) did not improve feed efficiency of birds on the day 35 experiment.

The lowest FCR observed in the group of birds fed corn-SBM diets added with Synbiotics showed the efficacy of this Syntbiotics product to increase the gut health to a good condition of enzymes to digest nutrients (Table 6), leading to more nutrients available to the birds. In addition, birds to eat more which leads to an increase in body weight gain.

Regarding the main effects, the present study shows that the birds fed on a diet containing rice bran and sago had better growth performance than those of the non-sago diet. The high feed intake of birds fed on diets containing rice bran and sago during the starter and grower phases (Table 3 and 4) was in agreement with Nalle et al. (2017) and Nalle et al. (2021). The factor which may contribute to the high palatability of the rice bran-sago diet was the physical characteristics (color, texture, and taste) of feed. Ferket and Gemat (2006) explained in their review that

Table 6. The Effects of Treatment Diets on Total Nutrient Digestibility Coefficients and Apparent Metabolizable Energy of Broiler Chickens

\begin{tabular}{|c|c|c|c|c|c|c|c|}
\hline \multirow{2}{*}{$\begin{array}{l}\text { Type of } \\
\text { Diets }\end{array}$} & \multirow{2}{*}{$\begin{array}{c}\text { Feed } \\
\text { Additive }\end{array}$} & \multicolumn{6}{|c|}{ Digestibility Coefficient } \\
\hline & & $\mathrm{CP}$ & $\mathrm{P}$ & NDF & Starch & AME & AMEn \\
\hline \multirow{4}{*}{$\begin{array}{l}\text { Corn- } \\
\text { SBM }\end{array}$} & Control & 0.455 & 0.226 & 0.535 & 0.859 & $12.01^{b}$ & $11.39^{\mathrm{b}}$ \\
\hline & Avi+Phy & 0.615 & 0.509 & 0.689 & 0.891 & $13.38^{\mathrm{ab}}$ & $12.52^{\mathrm{ab}}$ \\
\hline & Allzyme & 0.634 & 0.563 & 0.742 & 0.893 & $14.28^{\mathrm{a}}$ & $13.39^{\mathrm{a}}$ \\
\hline & Synbiotics & 0.558 & 0.335 & 0.591 & 0.884 & $12.61^{\mathrm{b}}$ & $11.88^{\mathrm{b}}$ \\
\hline \multirow{4}{*}{$\begin{array}{c}\text { Corn-rice } \\
\text { bran-sago- } \\
\text { SBM }\end{array}$} & Control & 0.521 & 0.396 & 0.640 & 0.844 & $12.94^{\mathrm{ab}}$ & $12.26^{\mathrm{ab}}$ \\
\hline & Avi+Phy & 0.599 & 0.447 & 0.594 & 0.856 & $12.47^{\mathrm{b}}$ & $11.72^{\mathrm{b}}$ \\
\hline & Allzyme & 0.543 & 0.413 & 0.669 & 0.824 & $11.98^{\mathrm{b}}$ & $11.28^{\mathrm{b}}$ \\
\hline & Synbiotics & 0.555 & 0.391 & 0.713 & 0.842 & $12.84^{\mathrm{ab}}$ & $12.12^{\mathrm{ab}}$ \\
\hline SEM & & 0.042 & 0.063 & 0.055 & 0.018 & 0.521 & 0.474 \\
\hline \multicolumn{8}{|c|}{ Main Effects } \\
\hline \multicolumn{8}{|c|}{ Type of Diets (TD) } \\
\hline \multicolumn{2}{|l|}{ Corn-SBM } & 0.565 & 0.413 & 0.639 & $0.882^{\mathrm{a}}$ & 13.07 & 12.29 \\
\hline \multicolumn{2}{|c|}{ Corn-rice bran-sago-SBM } & 0.554 & 0.412 & 0.654 & $0.841^{\mathrm{b}}$ & 12.56 & 11.85 \\
\hline \multicolumn{2}{|c|}{ SEM } & 0.021 & 0.032 & 0.027 & 0.009 & 0.261 & 0.237 \\
\hline \multicolumn{8}{|c|}{ Feed Additive (FA) } \\
\hline \multicolumn{2}{|c|}{ Control } & $0.488^{b}$ & 0.311 & 0.588 & 0.852 & 12.47 & 11.82 \\
\hline \multicolumn{2}{|l|}{ Avi+Phy } & $0.607^{\mathrm{a}}$ & 0.478 & 0.641 & 0.874 & 12.92 & 12.12 \\
\hline \multicolumn{2}{|l|}{ Allzyme } & $0.588^{\mathrm{a}}$ & 0.488 & 0.706 & 0.859 & 13.13 & 12.34 \\
\hline \multicolumn{2}{|l|}{ Synbiotics } & $0.556^{\mathrm{ab}}$ & 0.373 & 0.652 & 0.863 & 12.72 & 12.00 \\
\hline \multicolumn{2}{|l|}{ SEM } & 0.029 & 0.045 & 0.039 & 0.013 & 0.369 & 0.335 \\
\hline \multicolumn{8}{|c|}{ Probabilities, $\mathrm{P}<$} \\
\hline \multicolumn{2}{|l|}{ TD } & NS & NS & NS & $* *$ & NS & NS \\
\hline \multicolumn{2}{|l|}{ FA } & $*$ & NS & NS & NS & NS & NS \\
\hline \multicolumn{2}{|l|}{ TD $x$ FA } & NS & NS & NS & NS & * & $*$ \\
\hline
\end{tabular}

${ }^{\mathrm{a}, \mathrm{b}}$ Means of column with the superscripts significant difference $(\mathrm{p}<0.05),{ }^{*}$ : Significant $(\mathrm{p}<0.05) ;{ }^{* *}$ : Significant $(\mathrm{p}<0.01)$;NS: Not Significant $(\mathrm{p}>0.05) ; \mathrm{CP}=$ Crude Protein; $\mathrm{P}=$ Phosphor; NDF $=$ Neutral Detergent Fiber; AME = Apparent Metabolisable Energy; AMEn = Nitrogen Corrected Apparent Metabolisable Energy. Avi-Phy = Avizyme and Phyzyme; All = Allzyme SSF E; Syn = Synbiotic Probio FMplus. 
the color and texture of feed particles are the factors that could attract the birds to collect the feed. Te Pas et al. (2020) explained that one-day-old chick showed graded responses to different odors and showed sensitivity to different odorants. The chicks also prefer certain feed colors such as orange, blue and green (Ferket and Gemat, 2006). In the present experiment, the color of the sago diet was reddish due to the red color particle of sago. Regarding the taste of feed, their tactile cells in the bird's mouth play a significant role to intake or reject the feed (Neves et al., 2014; Ferket and Gernat, 2006). Te Pas et al. (2020) reported that heavier breed chickens have more taste buds than lighter chicken breeds.

The improvement in feed intake of birds during the starter and grower phases resulted in the improvement in the body weight gain of birds (Table 3 and 4). The present results agreed with Nalle et al. (2017, 2021), who reported an increase in the growth performance of broilers fed sago diets. Birds fed rice-bran-sago diets also had better feed efficiency (Table 3 and 4). The high feed efficiency of birds fed diets containing rice bran and sago during was related to the ability of birds to digest and absorb the dietary nutrients. Scott (1995) explained that growth rate and feed efficiency depended on the capability of birds to consume, digest, metabolize and absorb dietary nutrients. A postponement of one day in the time taken to achieve a specific market weight could increase feed used for maintenance by almost 3\%, equivalent to an increase in FCR of 0.06 . The body weight gain and feed conversion ratio are influenced by feed intake (Ferket and Gernat, 2006; Balami et al., 2018; Scott, 1995).

The addition of $40 \mathrm{~mL}$ of Synbiotics per liter of drinking water for 24 hours a day did not improve the growth performance of birds. The unchanged growth rate of birds was because of unchanged nutrient digestibility and AME/n (Table 6). According to Neves et al. (2014), nutritional quality is the main factor responsible for the remarkable growth rate of the birds. The present study showed a better result in the body weight gain of birds than the previous study
(Nalle et al., 2021). The difference was probably due to the difference in the level of synbiotic Probio FMplus and the individual response of birds used. The study by Nalle et al. (2021) used $20 \mathrm{~mL}$ of synbiotic Probio FMplus per liter of drinking water for 8 hours/day during the trial period.

The addition of enzymes decreased the growth performance of birds during the trial periods, which was not consistent with Nalle et al. (2020). The difference was probably due to the difference in the concentration of complex and multi-enzymes used. In the present study, the level of multi-enzymes Avizyme and Phyzyme used was $0.10 \%$ and $0.05 \%$, respectively, while in the study by Nalle et al. (2020), the dose of Avizyme and Phyzyme used was $0.05 \%$ and $0.01 \%$, respectively. The level of Allzyme SSF used in the present study was $0.05 \%$, while Nalle et al. (2018) used $0.02 \%$ in their experiment.

\section{Digestive Tract Development, Nutrient digest- ibility and Energy Values}

The growth and development of the gastrointestinal (GIT) tract are essential for broilers because the GIT tract plays an essential role in the digestion and absorption of dietary nutrients (Aguzey et al., 2018). The size, morphology, and functionality of gastrointestinal tract is very crucial in supporting broiler chicken to cope with the different environmental condition. In a review by Svihus (2014), it was explained that the functionality of the digestive tract in birds is pivotal for optimal performance, and diet composition, form, and feeding system might affect the digestive function. The author also explained that the addition of feed additives such as enzymes and pre-or probiotics can modify the functionality of the digestive tract.

The birds fed a corn-SBM diet supplemented with complex enzyme (Allzyme SSF -E) had the heavier and longer sizes of the liver, proventriculus, gizzard, and caecum (Table 5) compared to other treatments. The average liver size of birds fed a corn-SBM diet supplemented with Allzyme SSF was higher $(28.9 \mathrm{~g} / \mathrm{kg} \mathrm{BW})$ than the liver size of birds fed the maize-SBM diets as 
those reported by Zaefarian et al. (2019) and Nalle et al. (2010). The enlarged liver size found in the present study was probably induced by excessive dietary energy intake (carbohydrate metabolism) (Whitehead, 1979). As seen in Table 6, the energy values (AME and AMEn) of the corn-SBM diet supplemented with Allzyme were higher than other treatment diets.

The higher empty gizzard empty weight of birds in the corn-SBM diets compared to the rice -bran-sago diet was probably because of the difference in the proportion of particle size. CornSBM diet has a higher proportion of corn compared with the rice-bran-sago diet. The particle size of corn was slightly bigger than the particle size of rice bran and sago. The effect of particle size on gizzard size has been well documented (El-Wahab et al., 2020; Mtei et al., 2019; Selle et al., 2019; Zaefarian et al., 2016; Pacheco et al., 2013).

In a review by Tallentire et al. (2016), they explained that compared to other animals, poultry depends on enzymatic digestion because their colons are too short and mostly lack the bacteria that support other animal species in the digestion. Thus, the expectation of the addition of exogenous enzymes would improve the nutrient digestibility of the poultry diet. The present result showed that the enzyme supplementation in corn-SBM diets improved the digestibility coefficient of crude protein (DCCP), phosphor (DCP), and NDF (DCNDF) (Table 7). The improvement of DCCP in corn-SBM diets supplemented with Avizyme+Phyzyme and Allzyme SSF-E was owing to protease in Allzyme SSF and Avizyme. The present result agreed with Troche et al. (2007). Besides, phytase and fiberdegrading enzymes may also contribute to the increased protein digestibility. However, this improvement in crude protein digestibility (Table 6) did not improve body weight gain (Table 3). The improvement of $\mathrm{P}$ and NDF was due to phytase, xylanase, $\beta$-glucanase, cellulase, and pectinase. Phytase could reduce the formation of phytate-nutrient interactions, thus improving their digestion and absorption. The significant increase in the AME and AME values of birds fed corn-SBM diets supplemented with enzymes might be due to the improvement of NDF digestibility (Table 7).

As seen in Table 7, the starch digestibility coefficient in the corn-SBM diet was higher than the corn-rice bran-sago-SBM diet. This could be explained by the difference in antinutritional factors and starch characteristics in both treatment diets (starch granules, amylase: amylopectin ratio, and encapsulation and crystallinity) (Herwig et al., 2019; Magallanes-Cruz et al., 2017). The lower anti-nutritional factors (ANFs) in the corn-SBM diet than that of the rice bran-sago diet. As reported by Nalle et al. (2021), sago contains $20.6 \%$ NDF, $1.27 \%$ phytic acid, $0.11 \%$ tannins, $0.28 \%$ total phenol and $1968 \mathrm{mg} / \mathrm{kg}$ flavonoid. While rice bran contains a high level of phytic acid (5.9 to 6.09\%) (Canan et al., 2011). Phytic acid reduces the activity of several enzymes including amylase which is responsible for starch digestion, leading to low availability of starch (Woyengo and Nyachoti, 2013; Santos, 2011; Singh, 2008). Woyengo and Nyachoti (2013) reported that phytic acid reduces the activity of carbohydrases by binding to (1) The digestive enzymes, (2) dietary protein that is closely related to starch, and (3) through phosphate linkage. In a review by Singh (2008), it was explained that phytic acid decreased starch digestibility by $60 \%$ compared with a control treatment.

Regarding the main effect of FA, the significant increase in DCCP of birds in the group of multi and complex enzymes was due to the efficacy of protease. However, this improvement did not ameliorate the growth performance of birds in these treatments. This condition may be due to the absorbed protein was not enough to compensate for the slow growth during the starter period.

The present study demonstrated that the corn-SBM diet containing rice bran and sago was more palatable than the corn-SBM diet without rice bran and sago. Using an overdose of enzymes increased crude protein digestibility but did not improve the growth performance of birds. The supplementation of enzymes and synbiotics 
in rice bran-sago diets did not improve the growth performance, dietary nutrient digestibility, and energy values.

From a practical point of view, the supplementation of enzymes in the corn-SBM diets may produce better productivity when the diet is low in energy content. While the supplementation of Allzyme SSF-E, Avizyme + Phyzyme, and synbiotics in the rice bran-sago diet will produce better performance when applied for 35 days or longer. Further studies are needed to evaluate the efficacy of Allzyme SSF, Avizyme, and Phyzyme on corn-SBM diets (with and without rice bran-sago) which are different in $\mathrm{Ca}$ : $\mathrm{P}$ ratio and energy: protein ratio. The fiber fraction, oligosaccharide, amylose, and amylopectin contents of sago are also important to be evaluated in the future.

\section{CONCLUSION}

The present study proves that the treatment combinations produced different growth performance responses of birds. The birds fed the corn-SBM diets (with and without rice bran and sago) supplemented with synbiotics had better growth performance than those fed the cornSBM diets supplemented with multi and complex enzymes. The complex and multi enzymes work well in the rice bran-sago diet. The birds fed rice bran-sago diets supplemented with Allzyme SSF-E produced better productivity than those who received corn-SBM diets added with Allzyme SSF-E. The addition of multi and complex enzymes in the corn-SBM diet resulted in higher nutrient digestibility and AME/n values, but it did not improve the growth performance.

\section{ACKNOWLEDGMENTS}

The authors would like to thank the State Polytechnic of Agriculture Kupang for providing funding for this research (contract number: 01/ P2M/DIPA.023.18.2.677616/2020). Our thanks are also given to Japfa Comfeed Tbk. and Alltech Indonesia for their in-kind contributions.
The valuable assistance of Selviana Us Olin, Yustus Matamtasa, Johanes Jehadu and Romualdus Jerahu is fully appreciated.

\section{REFERENCES}

Abdollahi, M. R., B. J. Hosking, D. Ning and V. Ravindran. 2016. Influence of palm kernel meal inclusion and exogenous enzyme supplementation on growth performance, energy utilization, and nutrient digestibility in young broilers. Asian-Australas. J. Anim. Sci. 29(4):539-548.

Aguzey, H. A, Z. Gao, H. Wu and G. Cheng. 2018. Influence of feed form and particle size on gizzard, intestinal morphology and microbiota composition of broiler chicken. Poult. Fish Wild Sci. 6: 196

AOAC. 2005. Official Methods of Analysis of AOAC International. $18^{\text {th }}$ ed. Assoc. Off. Anal. Chem., Arlington.

Balami, A. G. S. J. Enam, A. G. Sule, M. Y. Patrobas, P. A. Abdu, M. A. Chiroma, A. M. Wakawa and T. Aluwong. 2018. The relationship between feed conversion ratio, feed intake and body weight gain of broilers fed Moringa oleifera leaf supplemented feed following challenged with very virulent infectious bursal disease virus. Adv. Anim. Vet. Sci. 6(6): 227-233. http:// dx.doi.org/10.17582/ journal.aavs/2018/6.6.227.233

Bao, Y. M., L. F. Romero and A. J. Cowieson. 2013. Functional patterns of exogenous enzymes in different feed ingredients. World's Poult. Sci. J. 69: 759-774. doi:10.1017/S0043933913000792.

Canan, C., F. T. L. Cruz, F. Delaroza, R. Casagrande, C. P. M. Sarmento, M. Shimokomaki and E. I. Ida. 2011. Studies on the extraction and purification of phytic acid from rice bran. J. Food Comp. Anal. 24:1057-1063. doi:10.1016/ j.jfca.2010.12.014

Coppedge, J. R., L. A. Oden, B. Ratliff, B. Brown, F. Ruch and J. T. Lee. 2012. Evaluation of nonstarch polysaccharide- 
degrading enzymes in broiler diets varying in nutrient and energy levels as measured by broiler performance and processing parameters. J. Appl. Poult. Res. 21(2):226234.

El-Wahab, A. A., J. Kriewitz, J. Hankel, B. Chuppava, C. Ratert, V. Taube, C. Visscher and J. Kamphues. 2020. The effects of feed particle size and floor type on the growth performance, GIT development, and pododermatitis in broiler chickens. Animals. 10:1256. doi:10.3390/ ani10081256.

Ferket, P. R. and A. G. Gernat. 2006. Factors that affect feed intake of meat birds: a review. Int. J. Poult. Sci. 5:905-911. https:// doi.org/10.3923/ijps.2006.905.911.

Garcia, M.C., M. T. Benassi and M.S. Soares Jr. 2012. Physicochemical and sensory profile of rice bran roasted in microwave. Ciênc. Tecnol. Aliment. 32(4), 754-761. http:// dx.doi.org/10.1590/S010120612012005000097.

Gehring, C. K., M. R. Bedford and W. A. Dozier. 2013. Interactive effects of phytase and xylanase supplementation with extractable salt-soluble protein content of corn in diets with adequate calcium and nonphytate phosphorus fed to broilers. Poult. Sci. 92 :1858-1869. http://dx.doi.org/ 10.3382/ ps.2013-03010

Gomez, K. A. and A. A. Gomez. 1984. Statistical Procedure for Agricultural Research. $2^{\text {nd }}$ ed. John Wiley $\&$ Sons, New York.

Herwig, E., D. Abbott, K. V. Schwean-Lardner and H. L. Classen. 2019. Effect of rate and extent of starch digestion on broiler chicken performance. Poult. Sci. 98:3676-3684. http://dx.doi.org/10.3382/ps/pey580.

Hill, F. W. and D. L. Anderson. 1958. Comparison of metabolizable energy and productive energy determinations with growing chicks. J. Nutr. 64:587-603. https:// doi.org/10.1093/jn/64.4.587

Indonesian National Standard (SNI-01-2891). 1992. How to test food and beverages. Indonesian National Standard Agency. pp.
18-20. [full article in Indonesian language].

Kaur, S., S. Sharma, \& H.P.S. Nagi. 2011. Functional properties and antinutritional factors in cereal bran. Asian J. Food Agro-Ind. 4 (2), 122-131.

Latshaw. J. D. 2008. Daily energy intake of broiler chickens is altered by proximate nutrient content and form of the diet. Poult. Sci. 87:89-95 doi:10.3382/ps.2007-00173.

Magallanes-Cruz, P. A., P. C. Flores-Silva and L. A. Bello-Perez. 2017. starch structure influences its digestibility: a review. J. Food Sci. 82(9):2016-2023. doi: 10.1111/1750-3841.13809

Mukherjee, R., R. Chakraborty and A. Dutta. 2018. Role of fermentation in improving nutritional quality of soybean meal - a review. Asian-Australas. J. Anim. Sci. Vol. 29, No. 11 : 1523-1529. http:// dx.doi.org/10.5713/ajas.15.0627.

Nalle, C. L., V. Ravindran and G. Ravindran. 2010. Nutritional value of faba beans (Vicia faba L.) for broilers: Apparent metabolisable energy, ileal amino acid digestibility and production performance. Anim. Feed Sci. Technol. 156:104-111. https:// doi.org/10.1016/j.anifeedsci.2010.01.010

Nalle, C. L., V. Ravindran and G. Ravindran. 2012. Nutritional value of white lupins (Lupinus albus) for broilers:apparent metabolisable energy, apparent ileal amino acid digestibility and production performance. Animal, 6:4, pp 579-585 \& The Animal Consortium 2011. doi:10.1017/ S1751731111001686

Nalle, C. L., V. Ravindran and G. Ravindran. 2011. Nutritional value of narrow-leafed Lupin (Lupinus angustifolius) for Broilers. British Poult. Sci. 52:775-81. https:// doi.org/10.1080/00071668.2011.639343

Nalle, C. L., M. R. K. Yowi and D. R. Tulle. 2017. Nutritional value of putak: apparent metabolisable energy and growth performance. Int. J. Agr. Sys. 5:53-59. https:// doi.org/10.20956/ijas.v5i1.1170

Nalle, C. L. and M. R. K. Yowi. 2018. The efficacy of multy-enzymes supplementation on 
low energy corn-soybean meal basal diet containing rice bran on growth performance of broilers. Int. J. Agr. Syst. 6(2): 138-145

Nalle, C. L., A. H. Angi, M. A. J. Supit and S. Ambarwati. 2019. Aflatoxin and ochratoxin A contamination in corn grains and sago (putak meal) from different sources for poultry in West Timor, Indonesia. Int. J. Poult. Sci. 18:353-360. http:// doi.org/10.3923/ijps.2019.353.360

Nalle, C. L., Helda, D. Kusumaningrum, J. Pobas, A. A. Lay Riwu and M. A. J. Supit. 2020. The supplementation effects of multyenzymes and synbiotics on production performance, nutrient utilization, economic value and Salmonella spp content of broilers. Pakistan J. Nut. 19:51-60. http:// doi.org/10.3923/pjn.2020.51.60

Nalle, C. L., Helda, B Masus and J. Malo. 2021. Nutritional Evaluation of Sago of Gebang Tree (Corypha utan Lamk) from Different Locations in West Timor Indonesia for Broilers. Trop. Anim. Sci. J. 44(1):48-61. https://doi.org/10.5398/tasj.2021.44.1.48.

Neves, D. P., T. M. Banhazi and I. A. Naas. 2014. Feeding Behaviour of Broiler Chickens: a Review on the Biomechanical characteristics. Braz. J. Poult. Sci. 16(2):116. $\quad$ http://dx.doi.org/10.1590/1516$\underline{635 \times 16021-16}$

Nutrient Requirements of Poultry (NRC). 1994. $9^{\text {th }}$ Edn. National Academy Press Washington, D.C.

Pacheco, W. J., C. R. Stark, P. R. Ferket and J. Brake. 2013. Evaluation of soybean meal source and particle size on broiler performance, nutrient digestibility, and gizzard development. Poult. Sci. 92 :2914-2922. http://dx.doi.org/ 10.3382/ps.2013-03186.

Richards, M. P. and M. Proszkowiec-Weglarz. 2007. Mechanisms Regulating Feed Intake, Energy Expenditure, and Body Weight in Poultry. Poult. Sci. 86:14781490.

SAS Institute. SAS/STAT ${ }^{\circledR}$ User's Guide: Statistics. $\quad\left(\mathrm{SAS}^{\circledR}\right.$ University Edition- Free
Online Software). SAS Institute Inc., Cary, NC, USA. https://www.sas.com/en_id/ software/university-edition.html

Stefanello, C., S. L. Vieira, P. S. Carvalho, J. O. B. Sorbara and A. J. Cowieson. 2016. Energy and nutrient utilization of broiler chickens fed corn-soybean meal and cornbased diets supplemented with xylanase. Poult. Sci. 95:1881-1887. http:// dx.doi.org/10.3382/ps/pew070.

Svihus, B. 2014. Starch digestion capacity of poultry. Poult. Sci. 93:2394-2399. https:// doi.org/10.3382/ps.2014-03905

Tallentire, C.W., I. Leinonen and I. Kyriazakis. 2016. Breeding for efficiency in the broiler chicken: a review. Agron. Sustain. Dev. 36:66. http://www.doi.org/10.1007/s13593 -016-0398

Te Pas, M. F. W., J. M. J. Rebel, D. Schokker, R. Borg, N. J. H. Buddiger, B. J. Wood, M. V. van Krimpen, M. P. L. Calus and J. Park. 2020. Regulating appetite in broilers for improving body and muscle development - a review. J. Anim. Physiol. Anim. Nut. 00:1-16. http://www.doi.org/10.1111/ jpn. 13407

Troche, C., X. Sun, A. P. McElroy and C. L. Novak. 2007. Supplementation of Avizyme 1502 to corn-soybean meal-wheat diets fed to turkey tom poults: the first fifty-six days of age. Poult. Sci. 86:496-502.

Ward, N. E. 2014. Choosing enzyme solution depends on many factors. Feedstuffs. 86 (4):1-4.

Whitehead, C. C. 1979. Nutritional and metabolic aspects of fatty liver disease in poultry. Vet. Quart., 1:3, 150-157, DOI: 10.1080/01652176.1979.9693738.

Woyengo, T. A. and C. M. Nyachoti. 2013. Review: Anti-nutritional effects of phytic acid in diets for pigs and poultry-current knowledge and directions for future research. Can. J. Anim. Sci. 93:9-21. https:// doi.org/10.4141/cjas2012-017

Yasothai, R. 2016. Antinutritional factors in soybean meal and its deactivation. Int. J. Sci. Env. Tech. 5(6):3793-3797. 
Yegani, M. and D. R. Korver. 2013. Effects of corn source and exogenous enzymes on growth performance and nutrient digestibility in broiler chickens. Poult. Sci. 92 :1208-1220 http://dx.doi.org/ 10.3382/ ps.2012-02390.

Zaefarian, F., M. R. Abdollahi and V. Ravindran. 2016. Particle size and feed form in broiler diets: impact on gastrointestinal tract development and gut health. World's Poult. Sci. J. 72:277-290. doi:10.1017/
S0043933916000222.

Zaefarian F., M. R. Abdollahi, A. Cowieson and V. Ravindran. 2019. Avian Liver: The forgotten organ. Animals. 9:63. doi:10.3390/ ani9020063.

Zhu, H. L., L. L.Hu, Y. Q.Hou, J. Zhang and B. Y.Ding. 2014. The effects of enzyme supplementation on performance and digestive parameters of broilers fed cornsoybean diets. Poult. Sci. 93:1704-12. https://doi.org/10.3382/ps.2013-03626. 